\title{
Access to Justice for People with Disability in Nigeria: Therapeutic Day Care Centre (TDCC) as a Case Study ${ }^{1}$
}

\author{
By Chinwe Stella Umegbolu*
}

\begin{abstract}
Access to justice through the court system for non-disabled persons is trampled upon every day in Nigeria. One can then imagine the plight of the disabled persons most of whom live in abject poverty and constant discrimination from their respective families, religious congregation, educational sectors, Judicial practices and the ineffectiveness of the government policies, which clearly plummeted people's confidence in the social justice system as well as the entire political structure. Against this backdrop, this study presents the findings of the analyses of these discriminations and Injustices; stemming from basic amenities to prevailing cultural vices, religious practices and lack of commitment on the part of the government. To attend and implement the needs of the disabled persons, which are hindrances to access to justice for the disabled persons in Nigeria. Thus this writer used Therapeutic Day Care Centre (TDCC) as a case study by interviewing the people that work with them as well as primary and secondary data. The conclusion points to the needs of these 'special' groups or disabled persons that were explicitly listed herein to be strictly adhered and for the Nigeria Bar Association (NBA) to take a proactive stand to redress the lawful inadequacies so as to enhance their access to justice.
\end{abstract}

Keywords: Alternative Dispute Resolution; Multi-door courthouse; Litigation; Access to Justice; Disabled Person; Therapeutic; Human rights.

\section{Methodology}

To reiterate, in achieving the primary objectives of this study, this writer conducted an interview to reveal some of this untold hardship or people that work with them for so many years at the TDCC best describe issues facing these disabled persons. It is essential to point out the importance of an interview, is to provide credible research and gain an in-depth understanding of the prevailing issues that can contribute or hinders access for the disabled person, which is classified as a qualitative approach.

Consequently, employing qualitative research tools in data collection is vital; to add originality to this paper and fill the gap in the literature. However, due to

\footnotetext{
"PhD Candidate, Business and Law, Brighton Business School, University of Brighton. Brighton, UK. Email: c.umegbolu@ brighton.ac.uk.

${ }^{1}$ The authoress thanks Dr Adaeze Okoye, Senior Lecturer, Research Group Lead (Law, Justice and Society), Brighton Business School, University of Brighton), Dr. Claire- Michelle Smyth, Principal Lecturer, Brighton Business School, University of Brighton, and Mrs. Hildegard Maria Ebigbo, Directress, Therapeutic Day Care Centre, Abakpa Nike, Enugu State, Nigeria, for their support.
} 
COVID-19, the opinion of the participants was collected via Zoom and Whatsapp. Hence this writer could not reach more employees.

However, respondents were grouped under four categories. The Directress consists of (1) participant, the manager consists of (1) participant, the head teacher consists of (1) participant and teachers consist of (2) participants. All respondents are from the Therapeutic Day Care Centre (TDCC) Enugu - a school and workshop training for disabled and non-disabled persons in Nigeria.

All themes and sub-themes generated from the questions posed to the four categories of the interviews are analysed from page 8 of this work.

\section{Introduction}

It is a known fact that the court system in particular Nigeria, is currently congested and the time frame it takes to get justice from the courts is fast becoming a mirage than reality to the common man. ${ }^{2}$ The collaboration of the Lagos state judiciary and $\mathrm{NCMG}^{3}$ conceived the LMDC in a bid to proffer solution.

In simple terms, LMDC connotes the enhancement of dispute resolution practices with the integration of ADR in the court system. Certainly, this approach has enhanced access to justice to a great extent for the populace; however, it is rather unfortunate that there are no proper considerations for the disabled communities including the disabled in Nigeria to benefit from this laudable innovation. The above viewpoint was informed from my data collection in Lagos and Enugu. The question that comes to mind is if the non-disabled citizens' rights are not fully met, how then does the justice system seek to protect and preserve the rights of the non-disabled persons? In view of the foregoing, I would seek to engage with the idea of defining Access to justice, which is distinct from availability of access or accessibility. In so doing, I am going to point out the main traits, which are factors that also contribute in hindering access to justice for disabled citizens.

\section{Concept of Access to Justice and Accessibility}

Access to justice simply means the common man having the unequivocal right to access the court without obstructions. ${ }^{4}$ In other words, the fundamental nature of the process of access to justice is undoubtedly hinged on the availability of its access to all. Hence, the denial of access to justice by any means whatsoever, whether by failure of the system to make alternative provisions in relation to high cost of litigation to support the indigent in the society, or by any form of discrimination or exclusion of certain categories of persons from getting access to

\footnotetext{
${ }^{2}$ Umegbolu (2019) at 9.

${ }^{3}$ Kehinde Aina is the founder of the Negotiation Conflict Management Group (NCMG).

${ }^{4}$ Onyema (2013) at 3.
} 
justice, then the system is a monumental failure if the access to justice is not available to all its citizens whenever the situation arises.

The above viewpoint is backed by Section 36 (1) of the 1999 which stipulates 'that the common man is entitled to be treated justly and get fitting remedy from the court, which is within the ambit of the law and within his constitutional right as a citizen of Nigeria. ${ }^{5}$ On the other hand, Cambridge dictionary defined accessibility as "the fact of being able to be reached or obtained easily."

Flowing from the above, it is regrettable to note that neither the Courts premises in Lagos State nor that of Enugu State observes or implement that provisions for the interests of disabled persons. In the same vein, accessibility or availability in this context is making sure that all persons can wholly and successfully dialogue or talk with everyone involved in the court or ADR process, without accessibility impediments.

However, at the courts in Lagos and Enugu there were no post barriers on gutters, no ramps or handrails to aid disabled persons in the courts. No instructions or guidelines for the hearing impaired, no recorders, no sign language interpreters, and no provision for the blind either. The writer also noticed that the disabled parties cannot access the offices, rooms, including toilets (is too small) and even the roads is filled with stones, so even if they can afford a mobile wheelchair, the road is unmotorable, hence cannot be used by the disabled. One can argue that the relatives can assist them to access the courts but it is about equality, their constitutional right and inclusion which they are entitled to and which is guaranteed in section 36 (i) of the 1999 constitution of the Federal Republic of Nigeria; it is about proper access in the real sense of it and it is about sense of belonging which Maslow pointed out as an essential element a human being needs.

Suffice to say that Section 46 (4) (b) (i) \& (ii) of the Constitution of the Federal Republic of Nigeria, 1999 has made the following provisions

(i) "for the rendering of financial assistance to any indigent citizen of Nigeria where his right under this Chapter has been infringed or with a view to enabling him to engage the services of a legal practitioner to prosecute his claim, and (ii) for ensuring that allegations of infringement of such rights are substantial and the requirement or need for financial or legal aid is real."

Though the above provisions cover indigent citizen, however most disabled persons live in abject poverty in Nigeria, ${ }^{7}$ hence accessing the court and basic services $^{8}$ like engaging a lawyer or getting financial aid is farfetched. It is essential to point out that there are more than one million disabled people in Nigeria and yet it was just in 2017 that they had access to vote. ${ }^{9}$

To buttress the point stated above, Lauren Moses elucidated that

\footnotetext{
${ }^{5} 1999$ Constitution of the Federal Republic of Nigeria.

${ }^{6}$ Mcleod (2016) at 2.

${ }^{7}$ Birchall (2019).

${ }^{8}$ World Bank Group (2020).

${ }^{9}$ Moses (2017).
} 
"Most polling units were located in inaccessible places, and none provided braille or tactile ballots for voters who are blind or have low vision. At almost half of polling units in Edo, the placement of ballot boxes barred persons with disabilities from independently casting their ballots; this problem was even more acute in Ondo, where per'1sons with disabilities were unable to vote independently in 77 percent of polling units. Finally, observers' reports found that Form EC 4OH, with which INEC records the participation of persons with disabilities on Election Day, was not used at 45 percent of the polling units observed in Edo and 70 percent of those observed in Ondo."

The sentiment stated above could be likened to the state of the courts and the predicament faced by the disabled persons. To validate the above view is the assertions of Mr XY a beggar on the street of Ikeja. Whom I spoke with him on my way back from the courts and asked him if he knows about the MDC and he said no, that he has not heard about it before now. He went on to point out that he has no means of transportation, not to talk of money to pursue any sort of matter in any courts. He stated categorically that it is the same predicament for most disabled persons in Lagos State except for those born into wealth.'

Consequent upon that, one can contend that both access to justice and accessibility to the courts are far eroding the disabled persons in Nigeria. In the Nigeria courts, both access to justice and accessibility to justice can be said to be a challenge facing both the disabled and non-disabled persons, however, this discourse will focus on disabled persons.

The need for access to justice for disabled person should be of paramount interest to all and sundry especially the government and the judiciary because they are legitimate citizens of the country. Apart from that, the constitution of the Federal Republic of Nigeria under section 36 provides for equal rights and protection without discrimination of her citizens to access the courts and the right to dignity of her citizens not to be subjected to inhumane treatment. In other words, that equally includes the barrier-free full access, equipment that will enable them to have their day in court and full participation in court proceedings and mediation.

However, recent cases show otherwise; for example, a lady in the END SARS protests with a single limb (one leg amputated) that came out for protests- trekked for so many miles in the not-so-good roads. The protesters saw her predicament and got her a prosthetic leg worth 1.6 million naira (equivalent to $£ 3,258.63$ ) in less than 24hours. ${ }^{10}$

Equally, cases reported by Egboka et al, about the predicament of disabled prisoners like Femi who was denied a crutches or any other mobility aid and Taheeb who has undiagnosed psychosocial disability though does not suffer from physical disability but cannot recall key details of his case or when last he met his lawyers. ${ }^{11}$ This writer is of the notion that these cases go a long way to establish the fact that disabled persons suffer structural discrimination and marginalisation in Nigeria. However, the Inclusive Friends Initiatives have challenged the

\footnotetext{
${ }^{10}$ Umegbolu (2020).

${ }^{11}$ Egboka \& Bogart (2016).
} 
narratives of disabled persons to have access to basic needs of life, voting, and inclusion. $^{12}$

Before that, it was a norm in Nigeria that the life or living conditions of a disabled person do not matter so much unless they were born into wealth. ${ }^{13}$ The gut-wrenching examples of how they are left behind during violent conflict and difficulties in gaining employment validate the above-stated assertion. ${ }^{14}$ Recently, the Association of Lawyers with Disabilities in Nigeria (ALDIN) with support of the Disability Rights Fund advocates for the marginalisation of lawyers by lawyers with disability. ${ }^{15}$ To buttress their points and to further sensitize these issues, they printed out and circulated the disability rights protection acts and some of these highlights ${ }^{16}$ of the Disability Act, which is as follows:

a) Seaports, Railways and Airport facilities shall be made accessible to persons with disabilities. ${ }^{17}$

b) Any general information shall be translated into the accessible format appropriate to the person with disability. ${ }^{18}$

c) A Person with disability shall have an unfettered right to education without discrimination or segregation in any form, ${ }^{19}$ and Braille, sign language and other skills for communicating with person with disabilities shall form part of the curriculum of primary, secondary and tertiary institutions. ${ }^{20}$

d) In queues, person with disabilities shall be given first consideration and as much as possible, be attended outside the queue. ${ }^{21}$

e) A Public building shall be constructed with the necessary accessibility aids such as lifts. (Where necessary) ramps and other facilities that shall make them accessible to and useable by persons with disabilities. ${ }^{22}$

f) A person with disability has the right to work on an equal basis with others and this includes the right opportunity to gain a living by work freely chosen or accepted in a labour market and work environment that is open. $^{23}$

g) All employers of labour in public organisations shall as much as possible, have persons with disabilities constituting at least $5 \%$ of their employment. $^{24}$

\footnotetext{
${ }^{12}$ Inclusive Friends: What Violence means to us: Women with Disabilities Speak (2015).

${ }^{13}$ Ibid.

${ }^{14}$ Ibid, p. 15

${ }^{15}$ Pamphlet provided to this researcher by the school manager- "this pamphlet was made available by one of our ex-students who an intelligent young man with speech and hearing impairment. He is currently studying physics education at the University of Ilorin."

${ }^{16}$ Discrimination against Persons with Disabilities (Prohibition) Bill, 2018.

${ }^{17}$ Part V Section 3(1) Discrimination against Persons with Disabilities (Prohibition) Bill, 2018.

${ }^{18}$ Ibid.

${ }^{19}$ Ibid, at Section $20(1)$

${ }^{20}$ Ibid, at Section 21 (1)

${ }^{21}$ Ibid.

${ }^{22} \mathrm{Ibid}$, at Part II Section 4

${ }^{23}$ Ibid, at Part VI Section 28 (1).

${ }^{24}$ Ibid, at Section 38 (d).
} 
h) Persons with disabilities shall be encouraged to fully participate in politics and public life. ${ }^{25}$

To validate the above viewpoints the current Nigeria's President Muhammadu Buhari signed into law this Discrimination against Persons with Disabilities (Prohibition) Act, 2018, following nine (9) years of advocacy by disability rights activists. ${ }^{26}$ Despite this sensitisation and provisions of the constitution and disability act, these rights are not being implemented. Thus the disabled persons still face untold hardship in accessing the courts and other premises. ${ }^{27}$ Nwachukwu Egbunike provided a first-hand account of the pains some parents of these disabled persons face. Mr L.E. Umego and Mr J.C.U. Igbokwe stated that

"Our children with special needs were unloved, discriminated, and our families stigmatised. There seemed to be an invisible iron curtain that cut our children with special needs off from the rest of the world ${ }^{28}$

Flowing from the above, though this statement was made about eight years ago (2012) it seems that the stigmatisation and discrimination faced by both the disabled persons and their parents are still prevalent to date.

However, in recent years or in the 20's the disabled persons in Nigeria have been able to make their voices count by providing eye-opening details of what people with disability go through and they did not stop at that, they proffered a solution in a bid to eliminate these issues or to a certain extent curb it.

\section{Therapeutic Day Care Centre (TDCC) Nigeria as a Case Study}

This innovative centre, one of its kinds in Nigeria, has its main campus in Abakpa Nike, Enugu in the eastern part of the country for both the disabled and non-disabled students. ${ }^{29}$ The school has been able to educate, provide amenities and take care of the disabled children that have been sent to them and those that were abandoned by their parents because of their disability for over forty (40) years now. The manager of the school was able to highlight some of the challenges that disabled persons face in Nigeria in particular Enugu State.

\footnotetext{
${ }^{25}$ Ibid, at Section 17.

${ }^{26}$ Ewang (2019).

${ }^{27}$ Whitehead (2015).

${ }^{28}$ Egbunike (2012) at 305.

${ }^{29}$ It is owned by a German woman - Mrs Hildegard Ebigbo - who worked for five years in Germany with persons with disabilities and had an in-service training as a speech therapist.' She was honoured with the National honour of Bundesverdienstkreuz (Federal Order of Merit) by the German Ambassador to Nigeria, Herr Joachim Schmillen, on behalf of the President of the Federal Republic of Germany, for giving countless scholarship to the disabled and creating an 'enabling environment (disabled friendly) where non-disabled and disabled could have equal opportunities and co-exist together.' She is married to Professor Peter Ebigbo, a professor of clinical Psychology, College of Medicine, University of Nigeria, Enugu Campus.
} 


\section{The Issues or Challenges facing the disabled Persons in Enugu}

\section{The Need to Practice both Integration and Inclusion}

The manager and the Directress revealed, 'the meaning and the difference between integration and inclusion.'

The manager revealed,

"So what is integration? This can be illustrated by thinking of a school where disabled children can attend alongside the non-disabled children. It is a regular school, but the disabled persons have their classes to meet their level of needs. For example, let us say we have a class of hearing-impaired and we put them together, they have their sign language teachers and they are all in one place, so that is easier for them to learn at the same level and by the same teacher. They are allowed to come to a school where others who are non-disabled come to, interact with each other in the common areas and share the same experiences, but they still have their classrooms with their teachers. This is referred to as integration. However, we have now taken it further to practice both integration and Inclusion.

On the other hand, she pointed out

"Inclusion means having both non-disabled and disabled children in the same class. For example, in a class the disabled children have their support teachers helping them through the classwork, like children with Autism sometimes they can become agitated as such needs their space, fresh air and they want to run and that disrupt the classes some times. It is still a challenge even in an advanced society like Germany, who has reached a very high level of accepting disabled in society. There are still not many schools that practice Inclusion because it is costintensive, and the government will have to pay for support teachers to sit with these children with disability in the same classroom as the non-disabled children. Hence, it is not very widespread, but the idea behind it is very well accepted. It has been proven that it is suitable for both the non-disabled and the disabled, though the more severe cases are paired in their classroom. So the disabled children assimilate more into society because the school is the micro cosmos of the world they go into because we do not want to prepare them to self-exclude themselves from society. However, persons with mild disability will quickly develop social skills that will enable them to be integrated or assimilated into society. What we want to do is to make them as independent as possible so that when they leave the school, they will be able to function in the society on their own, which starts from the class - that is Inclusion. So that is what we practice here. You can imagine when people come from abroad, and they marvel at our success, we usually hear 'you guys do these things that are not easy to do.' However, we also face other difficulties, like, some parents do not want their wards to be in the same class as the disabled students."

The Directress revealed the "positive impact of such a concept that turned out to be quite successful.' She opines, "Because inclusive education stimulates the brain and brings out the numerous potential in these children." 
Vol. 7, No. 2 Umegbolu: Access to Justice for People with Disability in Nigeria...

Evidently, this very bold and brilliant practices of the TDCC to ensure that disabled people in Nigeria do not feel discriminated, secluded or marginalized, is commendable and a step in the right direction.

There is a need for the government, to stretch its tentacles and reach out to the disabled persons taking into full consideration of the Federal Republic of Nigeria 1999, the need for integration and inclusion of the disabled persons fully into the society, its educational sector, its justice system and all facet of life and existence. Hence the TDCC standard practice for equal opportunity as stipulated in the 1999 constitution and the disability act for the disabled persons is worthy of emulation and should be encouraged for the advancement of society.

\section{Educational Amenities not provided for disabled Persons}

The directress offers insights 'that the disabled persons want to have their school leaving certificate and BECE.' She went on to point out that

"Now tell me a child with cerebral palsy that cannot write but he has the knowledge in his head however there is no provision for them to be able to write under WAEC or under BECE. So what do we do? We have been going to the BECE office. The Manager had been fighting for this particular boy so that they could use a recorder and record him. There is hardly any provision for children with such disability. However, they have for the blind for BECE and extra minutes for the blind and deaf that is just it - they are not the only form of disability."

Another example given by the Manager is a 'child that has muscular dystrophy.' She states,

"His whole body shakes, and his mother has lost her husband and even one of his siblings to the same illness - it is genetic in their family. He needs to be recorded, then transcribed into a paper, and the paper needs to be submitted, but there is no provision for this. No government has passed this into law because, in the WAEC script, no provision was provided for children with cerebral palsy or muscular dystrophy. There are no provisions for individual cases with different forms of disability.

In the western world, there are provisions, and they have their exam tailored for speech and hearing impaired. They have sign time interpreters because sometimes they need someone to interpret, like a sign language interpreter, to interpret the instructions and all those kinds of things. Here in Nigeria, there is no provision for these officially in WAEC guideline."

On the other hand, teacher 2 supported the overhead views. She opines

"These disabled people want to be integrated into society later, for them to be able to get a job and feel proud that they have what another person of their age have. Even in exams, there is no proper awareness that they are children with disability. Also, they have to write exams; the general exam organized by the Basic Education Certificate Examination (BECE) does not take into consideration all of these. There are other forms of impairment other than visual impairment. These children also deserve to be able to write their exams and have their certificate given to them." 
What this means is that the disabled persons are currently given the same exams that a non-disabled person is given. There is no provision for support during the exams, which is needed as a result of their disability.

Investing in the Education of the disabled is a Waste

Head teacher 1 elucidated that 'must parents do not want to bring their disabled children to the school, so they rather withdraw them from our school and leave them at home to deteriorate.' She states

"But we had noticed that some of them do come back to us when they realized the standards we use in teaching is better than other schools and if their wards are not showing much improvement their fancy schools after a few years."

On the other hand, the manager revealed

"Basically, the school is built for the disadvantaged and the poor, but my vision is to bring it up the standard whereby the so-called poor are getting the best. Moreover, it does not matter what class they are; they can comfortably receive the best stimulation and education." When I came with my ideas and they said you are coming from abroad that is a different reality from the one here."

However, teacher 2 revealed that 'parents do not like paying for these services.' In her words, the "parents find it difficult to agree to pay school fees for their disabled children. They would pay for their non-disabled wards but would owe the school fees of their disabled child. To these parents, they feel that investing in such a child is useless."

Following through teacher 1 indicate "that some parents do not like to send their disabled children to school, and even when do they would refuse to pay their school fees."

The school's manager provided additional evidence for the above-stated views

"It takes a lot of sensitisation and counselling through the directress, head teachers, parents-teachers association to achieve progress in that regard."

Conversely, the directress elucidated, "that in Africa, there is a general attitude that you train a child so that later the child can take care of you. However, since many disabled persons may not be able to meet these expectations, some parents feel no need to bring their disabled children to school. They feel it is a hopeless cause."

\section{The Government}

Teacher 2 extends our knowledge on 'the lack of support from the government.' She pointed out 'government offers little to no support to the school. 
Instead, the school is taxed like a private business when the school survives as a result of funding from benevolent individuals.'

To buttress the points above, the school manager opined "the government does not offer financial help or subsidies or support; instead, we are taxed heavily."

The sentiments expressed above embodies the narrative of this theoretical study or reviewed literature that there is a clear indication of the lack of interest in the affairs and wellbeing of the disabled persons in Nigeria.

\section{The Difficulty faced by both disabled and Non-disabled to Secure a Job in Nigeria}

The directress evaluated the 'chances of non-disabled and disabled persons to get a job in Nigeria.' In her words,

"It is already difficult for non-disabled persons to find a job in Nigeria and so much more difficult for the disabled. We follow up with former students and see the difficulties they face in securing employment, especially with disabled persons. It is, therefore, our goal to train them to become self-employed. With help from their family members, they can open a small business that can help sustain their livelihood."

On the other hand, teacher 2 revealed that 'due to the lack of employment for the disabled persons they offer jobs.'

She states, "Some of the disabled persons that graduated from TDCC are offered employment here, in fact, they work here as we speak."

Evidently, I believe that the challenge for some of this organisation who do not employ disabled persons because they are not enlightened or trained to work with the disabled persons. Hence, confirming they are no equal opportunities as stipulated by the constitution for both the non-disabled and this disabled persons most especially for the disabled persons who need special care for them to function in their day-to-day activities.

\section{A Right to Religion}

On the contrary, Head teacher 1 indicates, "some churches will not even want anything to do with our children, but the new bishop is open-minded."

Conversely Teacher 1 illustrates how "The parish next to us sends a Reverend father to us when there is a free one to come and celebrate mass." She further revealed,

"You need to see how happy the children are each time we have a visit. Do you know why? Because they see themselves getting the same thing that non-disabled people get. They check the bible, and they ask what it is called. They dance and fellowship together in their own home (the school) because their parents leave them at home when they go to church because they embarrass them, they keep them at home and 
lock them up. For those that are Catholics, they go to church and see people receiving this bread on their tongue, and these are so interesting for them - so they want the same."

They wonder why they cannot receive the Holy Communion, and they even see their younger ones receiving it whenever they go to church or allowed to go to church. So we are able to get the church, the Bishop, to agree to give us the parish priest from the next station, to come and test them for catechism. Obviously testing them on a simpler level and beforehand we give them catechism lessons. The catechism lesson is based on their different level, so if they are non-disabled, we give them normal catechism. Those of our children who are non-disabled also enjoy the whole thing of receiving Holy Communion and therapy. Do you know it is such a big deal? Some of these students look up to it and those who have cognitive impairment and do not understand those doctrines are taught the simple things. Just come down to their level like who is God? Alternatively, how to make the sign of the cross, how to kneel. Then the reverend father comes and asks them these questions, and when it comes for receiving Holy Communion in Easter, they come to our station, which is called St Mary; they come and give our kids the first Holy Communion. Do you know how proud it makes their parents? Do you know how happy it makes these children? What their siblings can receive, they can now receive themselves. It is such an immense joy for everyone."

From the above, their religious communities who should be protecting and appealing on their behalf also marginalize the disabled persons.

\section{Analysis of the Findings}

From the above findings, there is sufficient evidence that corroborates with the reviewed literature or the theoretical perspectives in this work that demonstrates that the disabled persons in Nigeria suffer from structural discrimination, marginalisation and seclusion. Which is tantamount to no access to justice and accessibility for the disabled persons because if they have no access to education, employment, basic amenities and religion, what else do they have access to? Thus, I believe there is no justice in any shape or form for these special individuals.

\section{Other Challenges or Issues Affecting or Infringing on the Access and Accessibility of the disabled Persons in Nigeria}

Cultural vices: Teacher 2 revealed "these parents they feel investing in such a child is useless."

In view of this, I believe that cultural vices plummeted or reinforced why some parents feel this way- this is due to the stigmatisation faced by the parents of these disabled persons in some communities in Nigeria. For instance, in communities in the East while growing up I witnessed some parents locking disabled persons up in rooms for so many years - caned and chained because they 
are seen as an 'alu' (abomination). If the community found out, they have such children they will be marginalised and in the same view they are stigmatised. While this last statement is unreported theoretically or in the reviewed literature, however, teacher 1 highlighted or revealed this in the findings "They dance, fellowship together in their own home (the school) because their parents leave them at home. When they go to church because they embarrass them, they keep them at home and lock them up."

Additionally, BBC buttresses this view -they reported a case in recent years 'why some Nigerian parents lock up children and the mentally ill which is as a result of the stigma associated with such illness. 30

These cultural vices have played a role in the lives of most disabled persons in Nigeria to resort to seclusion, which has been met with disproportionate backing from the government and the judiciary who have neglected, failed and /or refused to lend their respective voices, and/or push to enforce the provisions of the Constitution of the Federal Government and disability rights act which states that the rights of disabled persons are equally as important as that of the non-disabled persons. I believe that if the Federal Government plays a pivotal role in enforcing the rights of disabled persons. It will nudge the relevant bodies, stakeholders and organisations to uphold or implement these provisions in their various sectors. I believe that if this is duly observed and implemented, then it will nudge the state government to provide those amenities needed duly in the High court premises in each state and at the Multi-Door Courthouses.

\section{Conclusion}

This work has been able to reveal that there is discrimination because of legal barriers posed by non- accessibility depicted herein. The remote working and socialisation introduced by the COVID-19 pandemic may seem to have rectified or reduced these problems in some sense.

However, one of the problems that the change to a remote system of living seemed to be able to solve is with a party that has physical challenges, like somebody on a wheelchair (as such needs wheelchair ramp). Then they do not need to go into the courts or MDC; they can settle their cases online. Nevertheless, for one to be able to settle cases or matters online, they have to be able to access the technology because one of the good things about COVID-19 is that it has heightened the use of technology. However, most disabled persons in Nigeria live in abject poverty, though not all, and have no access to such luxury.

Moreover, what may happen after COVID-19 and things go back to normal? The element of technology to deliver court sessions may remain after the pandemic but how many of such disabled persons can afford the technology, let alone knowing how to use them? The issue of poverty raises its ugly head, and it raises other problems and other needs, which will be for future research. It is evident that more sensitisation from the part of stakeholders, government and the judiciary alike, are highly needed.

${ }^{30}$ Orjinmo \& Adamu (2020). 
This study proffers a solution for a practical way to establish a sense of inclusion or belonging by supporting this institute and by building more schools like TDCC. Furthermore, to provide an infrastructure that incorporates the utility mentioned herein for the disabled with support from prominent organisations, like the Nigeria Bar Association (NBA) for the needs of these special groups of our society to be specifically recognized and implemented in a bid to enhance their access to justice.

Thus, the need to push for an enactment by way of a legislation that will see to the integration, inclusion, safeguarding and upholding the rights of disabled persons as entrenched in the Constitution of the Federal Republic of Nigeria, 1999 is crucial and the impact of government at all level, other relevant groups and stakeholders like the NBA cannot be overemphasized in achieving this great feat.

\section{References}

Birchall, J. (2019). 'Overview of social exclusion in Nigeria. K4D Helpdesk Report'. Brighton, UK: Institute of Development Studies. https://assets.publishing.service.gov. uk/media/5df7b6f740f0b60948b22593/685_Overview_of_social_exclusion_Nigeria. pdf

Egboka, A. \& J. Bogart (2016). 'Prisoners with Disabilities: Justice Delayed Means More than Justice Denied' in This Day 16.8.2016. https://www.pressreader.com/nigeria/ thisday/20160816/281788513462437

Egbunike, N. (2012). Dyed Thoughts: A Conversation in and from my Country. Ibadan, Oyo State, Nigeria: Feathers \& Ink.

Ewang, A. (2019). 'Nigeria Passes Disability Rights Law - Offers Hope of Inclusion, Improved Access' in Human Rights Watch 25.1.2019. https://www.hrw.org/news/20 19/01/25/nigeria-passes-disabilit-rights-law

Inclusive Friends: What Violence means to us: Women with Disabilities Speak (Nigeria Stability and Reconciliation Programme 2015) http://www/nsrp-nigeria.org/wp-con tent/uploads/2015/09/What-Violence-Means-to-us-Women-with-Disabilities-Speak. pdf

McLeod, S. A. (2016). Maslow's Hierarchy of Needs. Highgate Counselling Centre www. simplypsychology.org/maslow.html

Moses, L. (2017). 'Nigerian Disability Advocates Conduct First-Ever Election Accessibility Audits' at DEM works - National Democracy Institute 30.11.2017). https://www. demworks.org/nigerian-disability-advocates-conduct-first-ever-election-accessibilityaudits

Onyema, E. (2013). 'The Multi-door Court House (MDC) Scheme in Nigeria: A case study of the Lagos MDC.' In Apogee Journal of Business, Property \& Constitutional Law 2(7):96-130

Orjinmo, N. \& A. Adamu (2020). 'Why some Nigerian families lock up children and the mentally ill' (BBC News, 3 October 2020). https://www.bbc.co.uk/news/worldafrica-53893271

Umegbolu, C. (2019). 'Dispensation of Justice: Lagos Multi-Door Courthouse as a Case study' (Ongoing PhD research at the University of Brighton) at http://blogs.Brighton. ac.uk/chinwe/2019/08/13/5/

Umegbolu, C. (2020). 'End SARS: A Revolution by the people for the people on police brutality in Nigeria' at https://research.brighton.ac.uk/en/publications/end-sars-a-revo 
Vol. 7, No. 2 Umegbolu: Access to Justice for People with Disability in Nigeria...

lution-by-the-people-for-the-people-on-police-brut

Whitehead, N. (2015). Wheelchair Beauty Queen Sings for Toilets' at KUER 3.8.2015.

https://www.kuer.org/2015-08-03/wheelchair-beauty-queen-sings-for-toilets

World Bank Group (2020). 'Disability Inclusion - A Repaid Assessment'. https://openkno wledge.worldbank.org/handle/10986/34073

\section{Legislation}

Constitution of the Federal Republic of Nigeria, 1999.

Discrimination against Persons with Disabilities (Prohibition) Bill, 2018 